\title{
A REVISTA "O PEQUENO LUTERANO": NACIONALISMO E HIGIENISMO A PARTIR DA FÉ LUTERANA (1931-1966)
}

\author{
Patrícia Weiduschadt ${ }^{1}$ \\ Universidade Federal de Pelotas (UFPEL) \\ Beatriz T. Daudt Fischer ${ }^{2}$ \\ Universidade do Vale dos Sinos (UNISINOS)
}

\section{RESUMO}

O presente artigo trata da circulação, edição, produção e apropriação de um impresso denominado "O Pequeno Luterano", editado pelo Sínodo de Missouri (atual IELB) no período de 1931 a 1966, tendo como foco central os conteúdos referentes ao nacionalismo e ao higienismo, presentes em matérias seculares e religiosas. Um banco de dados foi criado especialmente como ferramenta de análise, sendo a mesma complementada por depoimentos orais (leitores infantis, professores e editores daquele período). $\mathrm{O}$ artigo analisa disciplinas de conhecimento secular, cujas temáticas estão entrelaçadas à política nacionalista; em seguida, desdobra questões referentes à política higienista que nas páginas da revista infantil aparecem diretamente relacionadas a aspectos morais e religiosos. A revista, circulando entre crianças das escolas paroquiais, também serviu como apoio didático, reforçando os principais conteúdos das disciplinas escolares. Ao mesmo tempo, conforme narrativas dos sujeitos evocando memórias do tempo pretérito, a revista ajudou a formar o aluno e o futuro fiel, cidadão e ainda hoje leitor.

Palavras-chave: Nacionalismo; higienismo; luteranismo; impressos; leitores.

\section{THE MAGAZINE "THE LITTLE LUTHERAN": NATIONALISM AND HYGIENISM FROM RELIGION LUTHERAN (1931-1966)}

\begin{abstract}
This present work is about the circulation, edition, production and appropriation of a print named "The Little Lutheran", edited by Missouri Synod (in Brazil, IELB) from 1931 to 1966, whose main focus was the contents referring to nationalism and hygienism, present in secular and religious subjects. A database has been created specially as a tool of analysis, being this tool complemented by oral testimonies (infant readers, teachers and editors from that time). The article analyses subjects of secular knowledge, whose themes are interrelated to nationalist politics; next, it unfolds issues referring to hygienist politics, which in the pages of infant magazines appear directly related to moral and religious aspects. The magazine, which circulates among the parochial school children, also served as didactic support, reinforcing the main topics of school subjects. At the same time, according to narratives from the subjects evoking memories from the past time, the magazine helped to form the student as a prospective, loyal citizen, and a reader up to today.
\end{abstract}

Keywords: Nationalism, hygienism, Lutheranism, prints, readers. 


\section{Introdução}

Este artigo trata da circulação, da edição, da produção e da apropriação do impresso "O Pequeno Luterano", direcionado ao público infantil de adeptos do Sínodo de Missouri no contexto pomerano, na localidade de Pelotas/RS. Destaca em especial os propósitos doutrinários presentes no impresso que, em determinado momento da história brasileira, passa divulgar também conteúdos seculares, escolares e/ou relacionados a demandas da política nacionalista e higienista da época.

Diante da importância do uso dos impressos ${ }^{4}$ para entender processos educativos, justifica-se a análise da revista: "O Pequeno Luterano". Um periódico, com objetivos religiosos e educativos, o qual fazia parte de um projeto de educação de uma instituição religiosa luterana, voltada para o público infantil, tendo como meta a difusão de princípios doutrinários, servindo como apoio didático nas escolas paroquiais. Tal revista era direcionada a crianças e produzida pelo Sínodo de Missouri, instituição religiosa luterana originária dos Estados Unidos, que se instalou no Brasil em 1900, atualmente é denominada Igreja Evangélica Luterana do Brasil.

A educação e as relações do Sínodo de Missouri no contexto pomerano foram discutidas anteriormente em dissertação de mestrado ${ }^{5}$, com recorte temporal diferente, abordando, em especial, os primórdios da fundação do Sínodo. Neste artigo aborda-se um dos meios educativos utilizados pelo Sínodo, a revista "O Pequeno Luterano" - editada em alemão gótico entre 1931 e 1939, denominada Kinderblatt. A partir de 1939, com a nacionalização do ensino, passou a ser editada em português até 1966.

Ao longo do tempo demonstrou um crescimento considerável, não só em quantidade, como o aumento do número de páginas, como em qualidade. A apresentação gráfica e editorial foi melhorando tanto em número e qualidade de imagens. Ocorreram inúmeras trocas dos editores responsáveis, mas todos eles com o mesmo perfil profissional e religioso: foram pastores e professores, formados pela Igreja do Sínodo de Missouri.

\section{A revista}

A revista "O Pequeno Luterano" esteve disponibilizada no acervo da Biblioteca do Seminário Concórdia, em São Leopoldo. A partir deste material, constituiu-se um banco de dados. O período de análise se deu entre 1931 - 1939 (a revista era denominada "Kinderblatt", Jornal das Crianças), e depois de 1939 - 1966 (com a nacionalização do ensino, denominou-se $\mathrm{O}$ Pequeno Luterano). O material coletado apresentou significativa densidade em termos quantitativos, contendo considerável números de periódicos e número de páginas. A seguir, é apresentada a tabela explicativa, com a relação do número de periódicos e do número de páginas, divididos por décadas.

Tabela 1 - Apresentação numérica dos periódicos e número de páginas

\begin{tabular}{|c|c|c|}
\hline Período & Número de periódicos & Número de páginas \\
\hline 1931-1939 (Kinderblatt) & 60 & 272 \\
\hline 1939-1949 (O Pequeno Luterano) & 85 & 501 \\
\hline 1951-1959 (O Pequeno Luterano) & 73 & 784 \\
\hline 1960-1966 (O Pequeno Luterano) & 59 & 782 \\
\hline Total & 277 & 2339 \\
\hline
\end{tabular}

Fonte: Análise da revista "Kinderblatt" e "O Pequeno Luterano" (1931-1966)

A revista manteve, geralmente, a periodicidade mensal, mas muitas delas circularam bimestralmente, em especial, nos meses de janeiro-fevereiro, meses das férias escolares. Em momentos de crise, houve pouca circulação. Na década de 1940, por exemplo, especificamente nos anos de 1945 e 1946, cada ano foram editados 4 e 5 
periódicos, respectivamente, demonstrando as dificuldades encontradas no período de nacionalização do ensino. Entretanto, poucos são os números a que não se teve acesso na análise. Faltam alguns números do ano de 1934 e 1935 e do ano de 1953. Cabe salientar que foi possível perceber o aumento quantitativo do material impresso, com crescente número de páginas da revista a cada década de sua circulação.

A quantidade de edições é relevante, totalizando, no período de 1931 a 1966, 35 anos de circulação. De 1931 até 1948, anualmente a edição somava 48 páginas. Quando a revista apresentava publicação bimestral, o número de páginas aumentava proporcionalmente. Desde 1949, houve um aumento de, em média, 50 a 136 páginas, anualmente. O conjunto do acervo investigado compreendeu 277 periódicos, totalizando 2.339 páginas.

A circulação da revista era intensa entre as comunidades e escolas organizadas pelo Sínodo de Missouri. Estas escolas, denominada paroquiais, desde o início do Sínodo no Brasil foram mantidas e fundadas. Eram atendidas pelos próprios pastores ou professores leigos e mantinham vínculos religiosos e materiais didáticos específicos. ${ }^{6} \mathrm{Na}$ década de 1950, são 1200 assinantes, em 1962 aparece a tiragem de 1400, mas a média das assinaturas dos leitores pagantes girava em torno de 1162. Em 1964 o aumento da tiragem é visível. Essa discrepância entre a tiragem e o número de assinantes na década de 1960, se deve muito em função do patrocínio recebido pela revista e a maior mobilidade de circulação fora do meio dos assinantes, como nas escolas.

Além da análise da revista, a pesquisa foi complementada com dados orais, realizou-se entrevistas com pessoas que tivessem sido leitoras na infância deste periódico, bem como professores e editores. A revista não foi pensada propositalmente para circular no espaço escolar como apoio didático. Mas, de acordo com a interlocução dos leitores, representada por crianças e alunos, é possível perceber a circulação deste impresso no âmbito educativo através das cartas enviadas pelas escolas e o engajamento dos professores e pastores na divulgação do periódico no espaço religioso e escolar. Entretanto, muitos aspectos da revista apontam para o seu uso na escola. A formação da criança como aluno/fiel é entrelaçada num mesmo projeto religioso e secular. Ou seja, ao mesmo tempo em que a revista investe em conteúdos doutrinários, ela não se descuida de conteúdos denominados como disciplinas gerais dos currículos escolares e também contempla, em determinado período histórico, alguns conteúdos advindos da política de estado, como o nacionalismo e higienismo.

De acordo com a análise, as disciplinas seculares são abordadas enfaticamente, buscando amparar o aluno/leitor/fiel na sua formação e conhecimento. A revista circulou praticamente entre os fiéis do Sínodo de Missouri, especificamente entre escolas paroquiais do Rio Grande do Sul, formadas predominantemente por descendentes de alemães, predominantemente entre solo gaúcho, mas também em Santa Catarina e Rio de Janeiro. Este grupo étnico, especificamente acaba sofrendo com a política do Estado Novo, através das tentativas de nacionalização do ensino ${ }^{7}$. Nesta realidade o movimento da nacionalização do ensino desestrutura as organizações comunitárias dos imigrantes, e instaura mecanismos, como proibição da edição em língua alemã, centralizando a educação com currículos únicos. Entre outras medidas, a proibição do uso da língua alemã nas escolas e o exercício de pastores e professores nascidos na Alemanha na educação foi uma das medidas repressivas para tentar desestabilizar as escolas étnicas. Para construir um nacionalismo era preciso destruir as diferenças culturais e formar neste grupo uma cidadania brasileira (SCHARTZMAN, 1984). Neste sentido, a disseminação de conteúdos nacionalistas têm, certamente, amparo nas políticas repressivas e restritivas do Estado 
Novo. Por isso, justifica-se nas páginas do impresso a visibilidade de conteúdos para além de doutrina religiosa.

\section{Aporte teórico-metodológico}

Além de análise documental, o estudo valeu-se de entrevistas tendo como sujeitos indivíduos que na época estiveram envolvidos com o periódico, seja como leitores ou como responsáveis pela editoração. Como aporte teórico, os estudos de Chartier (2002, 2000, 1996a, 1996b) constituem base fundamental, em especial em relação à apropriação, circulação e edição do impresso. Também Certeau (2011), através dos conceitos de estratégias e táticas: estratégia entendida como a tentativa da revista em dominar e influenciar o modus operandi dos seus leitores. O conceito de táticas ajuda a compreender algumas atitudes dos leitores e escritores para demarcar estilo próprio no trato com o periódico. Em outras palavras, o Sínodo de Missouri, responsável pela editoração do impresso, valia-se de estratégias educativas e formativas tanto na edição, como na produção e circulação da revista entre seus leitores. Estes, por sua vez, se valiam de táticas, isto é, não necessariamente interpretavam e/ou correspondiam aos propósitos editoriais, podendo aproveitar o periódico, por exemplo, apenas em para deleite lúdico. Em síntese, frente a determinados conteúdos, nem sempre os leitores atribuíram a importância que a instituição almejava.

\section{Estrutura do artigo}

Na primeira parte do artigo serão abordados os conteúdos seculares, entremeados por ideias nacionalistas e também de higienismo, na época política a ser disseminada no âmbito escolar. Por fim, são discutidos alguns aspectos, que permitem inferir não só a importância destes conteúdos para garantia do projeto doutrinário da revista, como também, conforme Certeau, verificar estratégias dos editores que, ao inserir tais conteúdos - unindo formação moral e cidadã - permitiram dar sustentação ao periódico, mantendo seus propósitos iniciais naquele contexto político.

De acordo com o banco de dados, os conteúdos que emergiram na análise apontaram o conjunto de conhecimento relacionados a Ciências, História, Português, Matemática, Gaúcho, Geografia, Textos Explicativos e Poesia, constituídas e denominadas na pesquisa, por conhecimentos seculares. Ao lado destes, foram levantados conteúdos relacionados à política higienista, especialmente durante as décadas de 1940-1960, ressaltando o Alerta sobre doenças e Higienismo. Também foi forte a política do Estado Novo, perpetuando seus ideais em décadas posteriores, tendo como conteúdos Civismo, Exaltação a Vargas, Obediência às Autoridades, Trabalho e Ufanismo. Evidentemente, muitos destes conteúdos se entrecruzam, como História Factual, Civismo e Ufanismo. Outros temas apareceram, como Eurocentrismo, Desenvolvimentismo e Política. Conhecimentos seculares foram introduzidos para serem apropriados pelo leitor infantil. Conforme verificou-se na análise do periódico, determinadas estratégias foram planejadas para tal apropriação. Um dos meios usados para este fim se constituiu no binômio instituição escolar-instituição religiosa: através do espaço da escola a revista circulou e se legitimou no contexto, daí a valorização destes conteúdos.

\section{Disciplinas Curriculares - Conhecimentos seculares}

Conhecimentos seculares, advindos de conteúdos escolares, e também do ideário demandado pela política nacionalista do período Vargas, constituíram grande parte dos textos. Assim, a revista, mesmo mantendo a preocupação central - expandir a doutrina e 
conquistar o engajamento do leitor pela interlocução permanente - propõe-se também a fornecer elementos do conhecimento de disciplinas curriculares. Ao mesmo tempo, ocupava-se com conteúdos inspirados, direta ou indiretamente, nas políticas governamentais e educacionais da época.

Esta preocupação, de fato, não iniciou nas décadas de 1930. Em período anterior a preocupação em adequar os valores nacionais a determinadas disciplinas já é visível. No início do século XX, o Brasil era um país com grandes deficiências educacionais. $\mathrm{O}$ analfabetismo da população era altíssimo, não havia política e preocupação do poder público com a questão educacional. Enfim, não havia o pensamento enraizado nos intelectuais e no governo brasileiro da necessidade de uma educação pública e laica. As conquistas educacionais da Europa nem chegavam perto da realidade brasileira. Havia iniciativas da Igreja Católica na formação educacional da sociedade de uma forma elitista e segregadora. $\mathrm{O}$ acesso a escola não era uma realidade nem de perto idealizada para a maioria da população.

Entretanto, de acordo com Tania Regina de Luca (1999) em que analisa a Revista do Brasil, alerta que a preocupação com educação relacionada com sentimento nacional é latente nas primeiras décadas de 1920. A busca de uma identidade nacional parece ser a força que impulsionou a intelectualidade brasileira para oferecer uma diretriz educacional unificada e parâmetros de cunho nacionalista para orientar os processos educativos em todo o país.

Então, o conhecimento secular, redefinido por um currículo que contemplasse a unidade nacional, era visível em diferentes orientações: planos governamentais, revistas destinadas aos professores, alunos, revistas infantis, etc. Assim, a revista "O Pequeno Luterano" organizou muitos de seus textos, apoiados na necessidade e de acordo com a política nacionalista.

Se a revista era usada como apoio didático, as matérias seculares precisavam ser abordadas, não somente a título de curiosidade, mas instituídas para o aprendizado, este, em grande medida, relacionado ao pensamento cristão luterano. No impresso, a noção religiosa e doutrinária não é desviada em nenhum momento do seu propósito, isto é, os textos de Ciência e História Factual não se desprendem da função moral e religiosa empregada pelo Sínodo.

Um dos textos publicados na revista intitulado "Milagres das folhas": conta-se a história de crianças conversando, falando do ar e das folhas, do gás carbônico e do oxigênio, referindo que se as crianças pudessem ter na escola um microscópio poderiam ver o que tem nas folhas. (O Pequeno Luterano, nov/1955). A mensagem revela os conhecimentos da ciência biológica. Conta sobre as inovações, como o microscópio, mas não deixa de relacionar todas as descobertas com a criação de Deus. Além das ciências, o conhecimento da Geografia também se entrelaça a estes valores.

O texto "Os Babilônios" é um exemplo ilustrativo sobre este tema. No início o redator sugere ao professor a utilização dos mapas:

Meninos, pedi ao vosso professor ou à professora vos mostrar os rios Eufrates e Tigre no mapa da Ásia. A linha de terra que se acha entre os dois rios se chama Mesopotâmia. Esta palavra significa justamente Entre Rios. A beira direita do Eufrates estava a famosa cidade da Babilônia (Vertido por Mueller, O Pequeno Luterano, dez, 1955, p. 5).

$\mathrm{Na}$ sequência do texto é abordada a explicação sobre a região geográfica babilônica, os costumes e o comércio, relacionando este conhecimento histórico e geográfico com os relatos do cativeiro do povo de Israel no Antigo Testamento. O texto é 
bem didático, por isso presume-se que fosse usado na escola. A redação faz relações e combinações dos conteúdos, sempre colocando em primeiro plano o conhecimento religioso.

Em muitas revistas e orientações didáticas é reforçada a necessidade de valorizar a nação territorialmente. De acordo com os estudos de Luca (1999), as páginas da Revista do Brasil e dos discursos de intelectuais havia uma preocupação com o ensino da História e da Geografia no ensino primário, numa tentativa de fortalecer o conhecimento do território. Valorizar o território onde se vivia era a maneira de valorizar a terra e a nação que os indivíduos pertenciam. Assim, era possível uma unidade nacional, embasada no conhecimento da geografia, atrelando a ela outras disciplinas como a história:

Coube à geografia propiciar a reconciliação entre a nação e sua história. $\mathrm{O}$ discurso sobre o território forneceu a moldura capaz de reenquadrar o passado, extirpando-lhe tensões e ambições que obstacularizavam a sua construção da identidade. Num caminho até certo ponto peculiar, a produção do espaço nacional ocupou o centro da cena, subordinando a história, que passou a ser encarada como narrativa dos grandes feitos que asseguraram, apesar de todas as adversidades, a posse da terra. (...) (LUCA, 1999, p. 97)

Neste sentido, é observável que há uma relação e valorização do bandeirante como um elemento de coesão nacional, como um mito que reconstruiu a nação. A disciplina da geografia era contundente porque havia um apoio de poder: unificar a partir do território. Além da noção territorial, outro fator que poderia contribuir no fortalecimento de uma unidade nacional era a questão da unidade lingüística que o Brasil possuía. Em certo sentido, o português era a língua oficial de um vasto país continental. (LUCCA, 1999)

Daí a importância dos conteúdos de Português, encontrados na revista "O Pequeno Luterano" voltarem-se aos aspectos gramaticais e linguísticos, mesmo relacionados ao conhecimento religioso, ou seja, aos conhecimentos da bíblia em geral, com charadas, adivinhações e palavras cruzadas. Assim, a relação entre conhecimento gramatical e bíblico é abordada de forma integrada. Um dos textos relativamente longo começa com um versículo bíblico e, em seguida, faz a análise morfológica deste versículo, denominando substantivos, adjetivos e verbos:

"Embaraçando sempre o escudo da fé, como o qual podereis apagar todos os dardos inflamados do maligno" (Ef. 6.16" [...] Há duas palavras no texto que falam de ações. Quais são? "Tomar" e "Apagar". Estas palavras são "verbos". Que nos manda fazer o texto lido? "Tomar o escudo da fé". Para apagar os dardos do maligno [...] (Adpat C. H. Goebel, O Pequeno Luterano, ago-set, 1963, p. 2, grifos da redação).

Em seguida o texto aprofunda a doutrina, partindo do conhecimento da gramática. Este entrelaçamento mostra formas diferentes de abordar o conteúdo, configurando estratégias da edição para seduzir as escolas, fornecendo certo subsídio ao meio escolar. Todos estes textos se encaixam nos conteúdos de Textos Explicativos, Matemática e Gaúcho.

A Matemática foi apontada nesta pesquisa, devido à valorização, em certa medida, do conhecimento matemático que se aplicava na educação paroquial em escolas étnicas alemãs. ${ }^{8}$

De forma lúdica, o conhecimento matemático se dava através de charadas, de brincadeiras e de descoberta de enigmas no intuito de desenvolver o raciocínio lógico. As 
habilidades concretas e abstratas do aprendizado matemático eram valorizadas, em grande parte, através do cálculo mental em forma de brincadeiras lúdicas e prazerosas.

Outra curiosidade em relação ao tópico Matemática: a relação dos cálculos com as histórias bíblicas, intituladas "Charadas Bíblicas". Nas escolas paroquiais, pelo que se constata no envio de relatos dos leitores/alunos ou dos professores, o currículo da matemática era bem aceito. Entre as histórias de conhecimento geral, as curiosidades envolvendo a matemática são apresentadas de inúmeras maneiras. Algumas ensinam cálculos de jogos de descoberta, outras contam a biografia de matemáticos, o modo como lidaram com o conteúdo. Alguns conhecimentos geométricos são ilustrados nas histórias. Uma história muito interessante assinada por Marthin Lutero e intitulada como "A Aritmética do cristão" relata que o crente deve somar as suas necessidades com auxílio de Deus e assim com a subtração, a divisão, a multiplicação e os pontos geométricos, exemplifica o que cada um significa na nossa vida (O Pequeno Luterano, jan-fev/ 1962, p 22).

Como a revista era editada no Rio Grande do Sul, em alguns momentos o impresso refere-se à valorização da cultura gaúcha, por isso optou-se em acrescentar o conteúdo "Gaúcho". Este tópico tem pouquíssima representatividade na revista. Em termos numéricos foram catalogadas somente 9 aparições. Em geral, o maior número deste item está localizado em histórias de conhecimento geral, envolvendo aspectos geográficos, culturais e históricos. Estas histórias aparecem como informações acerca dos aspectos relacionados anteriormente, muitas apontando curiosidades da cultura gaúcha. Há uma história de lição de moral que exalta o valor e o caráter do gaúcho, relacionando as virtudes desse povo como um ideal cristão a ser seguido (LINDEN, Wanda, O Pequeno Luterano, Honestidade de um gaúcho, ago/1964).

Em relação ao aspecto História factual e Poesia, além de fazer parte do conhecimento secular, estão circunscritos e entrelaçados com ao ideário nacionalista da época: década de 1940 com o Estado Novo, década de 1950 com o estado desenvolvimentista e anos 1960 com o retrocesso dos processos democráticos e com o surgimento da ditadura militar. Do mesmo modo, a Poesia estava ligada às Datas Cívicas com exaltação e ufanismo patriótico.

\section{Questão do nacionalismo}

A História Factual é assentada no ideário da história dos heróis, das guerras, com pouca criticidade. Os fatos falam por eles mesmos e corroboram os contextos. É importante salientar que logo no início da transição da revista do alemão ao português, há Exaltação da Política do Governo, sendo que os textos abordam aspectos do nacionalismo, elogiando o governo e reforçando valores morais e patrióticos.

O texto/poema homenagem ao presidente, acompanhado da imagem oficial de Vargas, é bem colocado nesta discussão. Alguns versos são transcritos abaixo: 


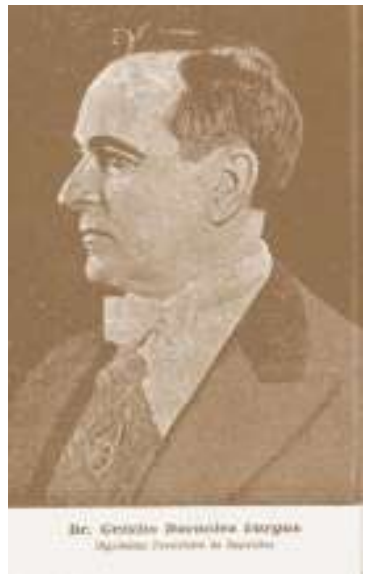

Homenagem ao presidente Getúlio

Getúlio Vargas, grandioso nome

Grande e sempre célebre na história,

Rico manto de progresso e paz

Bordados pelos louros da vitória [...]

O Brasil queria um brasileiro

Que soubesse a glória defender

E o gaúcho ilustre levantou-se

Legando a pátria nosso viver. [...]

(Herculano Junior, O Pequeno Luterano, mar-abr, 1943, p.7).

Figura 1-Revista O Pequeno Luterano- Imagem de Getúlio Vargas. mar/abr, 1943.

Provavelmente, a exaltação da política de Vargas consistiu em alternativa encontrada para a revista subsistir. Talvez possa ser identificada como tática realizada pelo impresso, já que a estratégia de dominação, neste caso, estava nas mãos dos órgãos de censura do governo getulista. ${ }^{9}$ (verificar o parágrafo...)

A imagem do presidente utilizada nas páginas da revista é a oficial, usada nas repartições e escolas. $\mathrm{O}$ texto em forma de poema revela o uso da propaganda em torno da figura que se construiu: a figura mítica do presidente, especialmente, entre o povo gaúcho. Interessante notar que essa exaltação não era referente ao vulto histórico do passado, mas à figura representada no presente. Ou seja, as formas de propaganda do governo Vargas incorporadas no impresso.

Pode-se considerar o governo Vargas com um alto grau de populismo e legitimado pela ameaça das guerras e do medo do comunismo. De acordo com o trabalho de Maria Helena Capelato (1998) sobre a propaganda de governos populistas como Vargas e Perón, a necessidade de implantar uma nova ordem no país não se daria sem um investimento massivo em propagandas de cunho nacionalista, em especial no campo da educação.

Inicialmente eram enfatizadas as grandes festas nacionais induzidas pelos órgãos públicos, representando assim o nascimento de uma nova ordem. Muitos estudos consideram que a propaganda do Estado Novo teve sua inspiração na Europa, nos governos nazistas e fascistas. Neste tipo de publicidade o apelo à emoção e a sensibilidade e a exaltação dos sentimentos era muito forte com um forte planejamento e assistência dos órgãos oficiais. (CAPELATO, 1998)

Outro ponto fundamental foi o fortalecimento do Ministério da Educação, tendo Gustavo Capanema a sua frente na organização deste órgão. Ele mostrou ser um homem de grande probidade pessoal, e totalmente dedicado à realização de objetivos que considerava de grande interesse público. (GOMES, 2000; SCHARTZMAN, 1984; SAVIANI, 2008)

Da mesma forma a análise de Maria Helena Capelato (1998) recai sobre constituição da propaganda no governo Vargas, mostrado o uso e a produção dos livros didáticos neste período. Este material exaltava a política nacionalista e continha textos que não apresentavam quase contradições e conflitos. Os livros e cartilhas eram em formato de catecismo e mostravam a propaganda do Estado Novo. Além dos livros didáticos, havia panfletos, programas em rádio e televisão, em que se objetivava legitimar o cidadão 
trabalhador e ordeiro. Assim, o aluno seria educado nesta perspectiva, o que importava era o interesse coletivo nacional. Esta identidade nacional coletiva seria alcançada através da educação colocando novos valores e orientações.

Já em outro contexto político, década de 1960, a redação repete esta exaltação ao governo no texto "Semana da Pátria", exortando a aceitar as autoridades sem contestar, orientando a não se falar mal dos órgãos policiais e dos governantes. Ressalta-se ali que as crianças devem ser bons cidadãos estudando e orando pelos governantes. No final, lembra D. Pedro I e outros vultos históricos brasileiros (O Pequeno Luterano, set/1965). Certo espírito de passividade e aceitação está presente nos discursos impressos, não interessando à redação fomentar discussões críticas em relação às políticas governamentais, mas orientar os fiéis a exercer o papel de cidadão de forma ordeira e passiva. Mais uma vez se confirma: orientação ao futuro fiel luterano era a formação religiosa, desconectada da formação crítica e contestadora. Não está sendo julgada a posição da instituição, apenas constatam-se os mecanismos e táticas usadas para escapar da visibilidade dos grupos dominantes da época. É evidente a posição em não se importar com a situação vivenciada, e sim exercer a religiosidade. Cabe aqui trazer o depoimento do professor e pastor Donaldo Schueller (leitor infantil da revista na década de 1940), que se refere a desvalorização do lado político nas situações enfrentadas pelos luteranos colocando apropriadamente experiências pessoais vividas:

[...] o princípio da minha infância era votar a favor do governo situacionista. Por quê? Porque o governo era o elemento da estabilidade, então quer dizer que uma posição de conflito no governo, de interferir na vida política, absolutamente não estava dentro destas comunidades. Aí se pode entender também este luteranismo meramente cultural, era a cultura, respeite-se isso, somos luteranos, respeite-se isso, e mantém-se então esta tradição luterana de como nós viemos. [...] É este princípio, respeitada a nossa liberdade tudo muito bem, então se o governo é autoritário ou não é, inclusive eles já vieram desta tradição, o governo era autoritário na Europa, monarquista, vem para a monarquia brasileira, [...] Quando se cria uma consciência de cidadania, e eu sou efetivamente cidadão, muito bem, não éramos cidadão antes da segunda guerra mundial, Getúlio Vargas começou a combater as comunidades de imigrantes. Porque a obrigação da língua portuguesa, um fim para nacionalizar estes elementos que não eram considerados nacionais. Quer dizer comunidades absolutamente brasileiras por várias gerações, que não estavam dentro do sistema da língua portuguesa, estavam fora. Eu senti isto na minha infância, éramos outra coisa, éramos nascidos no Brasil sem sermos brasileiros, não havia uma consciência de brasilidade, esta consciência tinha que ser formada e recentemente. Muito bem, surgem várias consciências, a de ser luterano, a de ser descendente de alemão, de ser brasileiro, como se concilia esta situação? Quer dizer que havia a situação de conflito, e a situação de uma abertura só pode surgir a partir daí ( Donaldo Schueller. Entrevista concedida dia 26 de julho de 2011)

Tal testemunho reforça a valorização da formação da cultura luterana, que se daria através da religiosidade, da escolaridade voltada aos princípios da germanidade e da doutrina luterana. Assim, no governo do Estado Novo, adaptou-se as novas condições, não deixando de defender o luteranismo e, ao mesmo tempo, não se importando muito com questões sociais e políticas do momento. O governo era considerado a instância não interventora da religiosidade, de sorte que a única tarefa dos cristãos seria apoiar e orar 
pelos governantes. A instituição entendia que não seria necessário contar com o apoio direto do governo nas questões da educação e religião, somente precisariam se adaptar a algumas regras. Não incomodar e não serem incomodados. Como exemplo citado pelo depoente, a construção da brasilidade foi realizada de forma passiva, acatando as normas do Estado Novo - evidentemente com resistência velada - para conseguir o que era considerado importante: a manutenção da religião. ${ }^{10}$

Dentro dessa perspectiva da exaltação ao governo, conteúdos apresentados à luz da História Factual mostram discursos e mensagens carregadas de elementos nacionalistas e ufanistas. Neste sentido, a História Factual descreve histórias sob a perspectiva da história tradicional, com relatos de guerras, de heróis, ou seja, sem nenhuma criticidade em relação aos fatos apresentados. Neste arcabouço de conhecimento, o "Nacionalismo" e as "Datas Cívicas" estão imbricados, uma vez que estas categorias reforçam a linha da história que se quer enfatizar.

O conteúdo da História do Brasil presentes nos currículos das escolas da época aponta para disseminação da história linear e eurocêntrica, solicitando heroísmo dos nomes dos descobridores, dos bandeirantes, dos exploradores (O Pequeno Luterano, Os primitivos do RS, ago/1947). Apresenta várias curiosidades de determinada época, tanto da época Colonial como do período do Império, de forma descontextualizada, como entretenimento, destituído de maior reflexão (O Pequeno Luterano, com o título "Você sabia que..", agoset/1963; set/1964; fev-mar/1966; jun/1966).

Nas primeiras décadas da revista em português (O Pequeno Luterano, 1939-1949), textos alusivos ao dia 7 de setembro, por exemplo, eram referenciados como a data nacional relevante. Em muitos momentos, o tema sugestivo nacionalista abre a capa de setembro com imagem e poemas associados, ou seja, as mensagens são eivadas de brasilidade e de comum acordo com o projeto estadonovista.
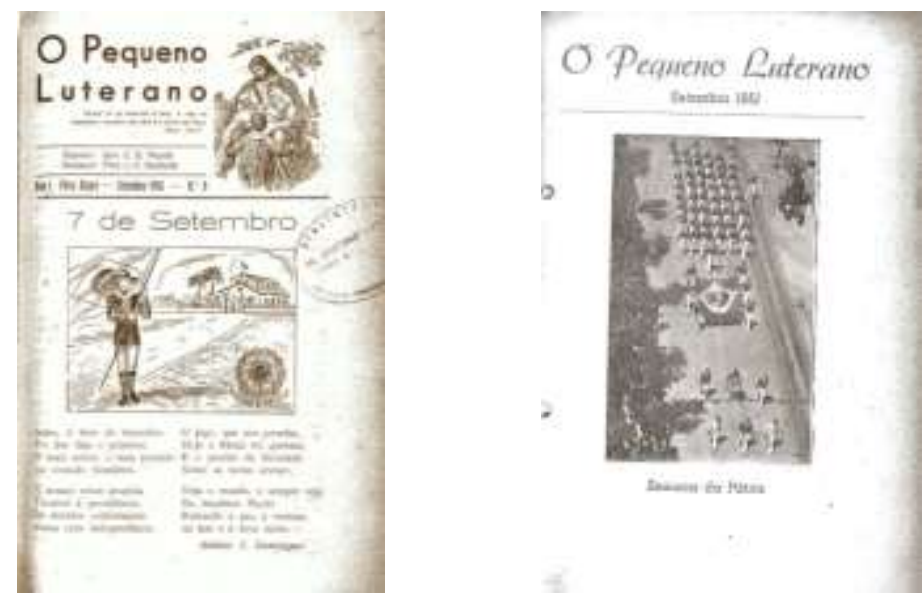

Figura 2- Revista O Pequeno Luterano- 7 de setembro. set,1943.

Figura 3-Revista O Pequeno Luterano- Semana da Pátria. set,1951.

Mas nas décadas de 1950-1960 o nacionalismo exposto nas páginas é nutrido por aspectos do governo desenvolvimentista e continua na mesma esteira da história ufanista e tradicional. Os próprios títulos destas histórias dão a ideia como o currículo escolar das escolas utilizava este veículo. Relacionam-se alguns títulos para ilustrar esta análise. A história "Heróis da Pátria" enfatiza o Dia do Soldado, dirige o leitor a celebrar a Pátria com várias histórias de feitos heroicos: a história versa sobre o corneteiro João José que, com heroísmo, na guerra, toca a corneta até o fim. Adiante, menciona-se a história de Duque de Caxias, herói humilde, que deu o seu café a um soldado (O Pequeno Luterano, jul- 
ago/1950); aparecem muitos relatos da gloriosa passagem de Humaitá, o patriotismo, Guerra contra o Paraguai e pormenores do glorioso feito, batalhas de feitos heroicos, etc.(O Pequeno Luterano, mar-abr/1953). Na década de 1960, as chamadas com o título "Histórias de nossa história", aparecem em quase todos os meses do ano de 1963 (O Pequeno Luterano, jan; fev; mar; mai; jun; jul; ago-sedt/1963) e em alguns meses de 1964 (O Pequeno Luterano, jan/fev; jul; ago; set).

Essas histórias relataram a biografia de heróis brasileiros do império, da república, da Guerra do Paraguai, da Inconfidência Mineira, entre outros. Todos os textos nacionalistas contemplam o ideário da história organizada em fatos e referem sempre a história oficial. Por vezes, são contados acontecimentos pitorescos de biografias e feitos heroicos, sem jamais questionar a conduta ou problematizar os fatos. Não há contextualização estabelecendo relações com o tempo presente vivenciado. Conforme já foi aludido, os conteúdos históricos reforçam ideias majoritárias daquele período, além de ratificar o projeto moral e cristão doutrinário da revista.

Um bom exemplo é o texto carregado dos preceitos moralistas e doutrinários, além da perspectiva ufanista exacerbada, "A Bandeira do Marquês de Olinda", que repete os feitos heroicos da Guerra do Paraguai, entrelaçado com o simbolismo dos valores pátrios:

O acontecimento que passarás a ler, meu amiguinho, serve como homenagem à nossa querida bandeira, símbolo de nosso grande e belo Brasil. No dia 13 de novembro de 1864 o vapor brasileiro 'Marquês de Olinda' viu-se aprisionado, de uma ora para outra, pelo exército paraguaio. [...] O oficial paraguaio ordenou com voz áspera: - Retirem esta bandeira de negros e levem-na para servir de tapete para o nosso chefe. Que ultraje! Que desaforo para o Brasil! ( O Pequeno Luterano, nov/1962, p. 7).

A história finaliza com a ocupação da capital paraguaia e o resgate da bandeira que estava servindo de tapete no Paraguai. A um oficial já velho coube trazer a bandeira de volta ao solo brasileiro. No final, a edição entrelaça a história repleta de fatos heroicos com a formação cidadã dos luteranos, revestidos de valores doutrinários:

Lembremo-nos, sempre, meus amiguinhos, Deus nos deu uma Pátria tão grande e tão linda. Devemos estar agradecidos ao bondoso Pai celestial por todas as bênçãos que nos dá e sempre de novo pedirmos que ele proteja a nossa Pátria contra tudo o que lhe possa ser prejudicial ( $\mathrm{O}$ Pequeno Luterano, nov/1962, p. 8).

O comportamento do cidadão deveria estar alinhado ao conformismo e passividade diante da realidade política apresentada. Apesar de o recurso usado ser a história da guerra passada, o presente também deveria ser relembrado nos feitos e fatos heroicos. O cidadão deveria deixar os governantes agir, o cristão deveria orar por eles, este o seu papel; as relações sociais são deixadas para a instância governamental. Pode-se perceber latente o uso destes valores englobando a História Factual e o Ufanismo entre vários elementos do ideário nacionalista já referido acima.

Outro momento de conflito no cenário mundial se deu a partir da década de 19501960, ou seja, o pós-guerra caracterizou-se pela polarização política entre Estados Unidos e União Soviética. Neste sentido, a revista, após defender um posicionamento neutro, reforça o seu alinhamento contra as ideias comunistas, justificando-se na perseguição religiosa daqueles países aos cristãos. Como exemplos, as histórias "Viagem para a 
China", contada em três partes. Na primeira, a revista oferece uma visão histórica, o texto conta que depois das cruzadas houve muitos homens na Europa que queriam viajar para terras estranhas (pedem às crianças para que localizem a Ásia no mapa); relata a história de Marco Pólo que, apesar, de ter sido europeu, viveu na China 17 anos, sendo enviado pelo imperador da China para outros lugares. Os europeus se admiravam que a China fosse um lugar civilizado; a muralha chinesa era admirada. No final da história, reforça-se o fato da China ser comunista, critica-se este regime, dizendo que muitos discordaram indo trabalhar em outros lugares (O Pequeno Luterano, jan/fev,1959). O segundo texto relata a China como uns dos países ricos em natureza, convidam os leitores a fazerem uma viagem: imaginar como se estivessem no porto de Shangai, com barcos de moradia, granjas de arroz, bichos de seda. Entretanto, criticam a política comunista, ao colocar no discurso as dificuldades de moradia dos trabalhadores chineses (O Pequeno Luterano, mar-abr/ 1959). O terceiro texto revela os costumes do povo, mostra a parte geográfica, as grandes fazendas, a cidade de Pequim, as ruas estreitas, os costumes alimentares, os costumes do cumprimento. Menciona a vida moderna, a escola para ler e escrever, a educação das meninas e enfatiza que em alguns lugares os missionários são tolerados. Ao final, são reforçados os males do comunismo (O Pequeno Luterano, mai/jun,1959). Os três textos em sequência apontam preocupação do impresso com os países comunistas, aludindo no impresso que este sistema pode prejudicar a difusãodo cristianismo.

Da mesma forma, no período histórico nacional de grande efervescência, década de 1960, a revista se mantém distante do momento político. Um discurso subliminar em relação aos fatos políticos apresenta a defesa de princípios demarcados por certa pseudoneutralidade. Ou seja, a revista orienta os leitores na educação cívica, moral e religiosa ao não envolvimento das questões políticas, mas se mostra contra a um sistema político comunista, justificando este alinhamento à defesa da organização religiosa e da autoridade.

Como se verifica, a menção às autoridades não se limitaram apenas à esfera familiar, escolar e religiosa. A obediência civil e pacífica ao Estado era instigada em textos direcionados, em especial, os de cunho nacionalista. Especialmente no período de nacionalização do ensino, textos engrandecendo os heróis da Pátria, insistindo na aceitação da condução pacífica dos governantes foram recorrentes. Mas as histórias de lição de moral, em que aspectos de obediência aos pais relacionados à doutrina são valorizados, especificamente aludindo o uso do quarto mandamento. Os filhos não devem descuidar dos seus deveres e respeitar aos superiores, porque, certamente, se não o fizerem, poderão ser castigados. As histórias de lição de moral levam à aplicação de condutas ou lembram sobre o castigo, o arrependimento e a subserviência, práticas importantes na conduta das crianças. Do mesmo modo, histórias bíblicas são apresentadas repletas de exemplos de obediência, enfatizando, a dedicação a Deus e a doutrina difundida pelo Sínodo ${ }^{11}$.

O Desenvolvimentismo, mesmo com menor número de recorrência na revista, destaca-se através dos pressupostos dos discursos nacionalistas presentes na revista. Alguns textos encontrados reforçam a ideia do país moderno, com mais ênfase a partir da década de 1950, tendo como exemplo a admiração dos monumentos, como o de Brasília, (Deus abençoe a nossa Pátria, O Pequeno Luterano, nov/1955) bem como o relato da natureza brasileira que precisava ser explorada ( $\mathrm{O}$ Pequeno Luterano, $\mathrm{O}$ assombroso Amazonas, out/1955). Mas alguns excertos mostram outros textos históricos, numa perspectiva de exaltação dos heróis e da nação. Este tópico chama atenção ao veicular na revista em forma de notícias da igreja, relatos de expansão e de resultados de missão da instituição (O Pequeno Luterano, Notícias da Igreja, nov-dez/1960).

O conceito Eurocentrismo foi constituído a partir de textos que colocavam o homem europeu, branco, cristão, e neste contexto, ainda, luterano, como o mais correto 
exemplo e modelo a ser seguido. Histórias de lição de moral reforçam essa ideia, que a missão e conversão destinada a povos africanos e asiáticos era uma obrigação dos povos cristianizados, ou seja, levar a verdadeira fé e os ensinamentos de Cristo aos pagãos (O Pequeno Luterano, João Paton - missionários entre os canibais, parte 1, set/1951). Muitas histórias, na sua maioria relatos reais, revelam biografias de missionários, contando que estes deixaram a sua vida confortável na "civilização" e foram morar em tribos e aldeias de costumes considerados pela instituição religiosa como "errados" e "perniciosos" (O Pequeno Luterano, João Paton - missionário entre os canibais, parte 3, mar-abr/1952). As histórias abordam os costumes religiosos destes povos e apontam para a necessidade e a urgência da conversão deles. Ainda, reforçam que temos que agradecer por termos a estrutura religiosa considerada "verdadeira".

É possível contextualizar todas estas ideias, pois neste período, a noção do respeito à diversidade étnica não era tão apregoada entre os meios culturais ocidentais.As histórias revelam estes missionários como homens exemplares, que devem servir, de fato, como exemplos para as crianças. Por sua vez, os leitores são instigados a fazer missão, não sendo necessário pregar a palavra aos pagãos em lugares longínquos, mas reforçar e disseminar práticas missionárias no meio em que vivem. $\mathrm{O}$ exemplo destes destemidos missionários reforçaria práticas comuns, como falar da palavra de Deus e salvação, propagando a mensagem a todos através do conhecimento religioso. Do mesmo modo, seria necessário orientar a conduta infantil, incutindo a certeza nestas crianças à participação em uma instituição considerada como a que detém os verdadeiros princípios doutrinários (O Pequeno Luterano, João Paton - missionários entre os canibais, parte 2, jan-fev/1952) ${ }^{12}$.

\section{A Questão do Higienismo}

Outro conteúdo insistentemente apresentado na revista é o que se refere ao movimento higienista, também abordado como conhecimento secular, mas com forte apelo moral. Nesta análise tais aspectos são classificados como Alerta de Doenças e Higienismo.

O movimento higienista da época, atrelado ao nacionalismo do Estado Novo, é reforçado pela dimensão da ordem e da moral. Há necessidade de controlar e moldar o espírito com ideais de nacionalismo e obrigações cíveis, agregado ao controle corporal através de práticas higienistas.

Tais ideias formaram todo um ideário na sociedade brasileira. Tal ideário esteve presente nas relações sociais e culturais, como a preocupação com o controle das epidemias, através da vacinação em massa, etc. Na escola, o movimento higienista pôde ser fortalecido com a inserção dos saberes médicos à pedagogia, ou seja, a figura do médico não deveria ser dispensada do meio escolar. Essa atuação não consistia somente na presença física, como inspetor, prescritor e examinador das condições dos corpos e da saúde das crianças, mas, presente em exortações e cuidados. Maria Stephanou (2006b) refere que a preocupação estava relacionada a uma concepção fisiológica, que examina o indivíduo detalhadamente (complete...), e que necessita da adesão social para levar a efeito os seus objetivos. A respeito disso, afirma:

Uma nova concepção de medicina, dessa maneira, estendia-se para uma 'leitura' médica dos fenômenos educativos: uma visão fisiológica do escolar, a importância atribuída a todas as atividades funcionais do ser vivo a serem consideradas pela escola - uma educação física, mental, intelectual, moral -, as condições do terreno e as predisposições herdadas ou constituídas pelos processos preventivos e pedagógicos. Além do 
mais, a concepção fisiológica estende-se para o social e pensa o indivíduo e a coletividade como absolutamente interdependentes: um indivíduo são contribui para uma sociedade sadia e, inversamente, uma sociedade em degeneração produz indivíduos imperfeitos [...] (p. 37).

Conforme o discurso da época, este conhecimento médico precisava ser apropriado pelos professores e pais, a sociedade funcional carecia de uma educação física, mental e moral. Estas três perspectivas estavam juntas e atreladas aos mesmos objetivos: formar pessoas sadias e ordeiras, que ocupassem sua mente com pensamentos pacíficos. Assim, os modos, tanto físicos quanto intelectuais, precisavam de controle por meio da educação. A ligação do médico com educadores necessitava ser cada vez mais estreita:

Da mesma forma que ao pedagogo competia apropriar-se dos conhecimentos científicos da biologia e da psicologia para compreender a criança e qualificar sua tarefa educativa, o médico na escola não exercia simplesmente medicina, mas constituía-se como educador. Ora, para o bom desenvolvimento de tão elevada função, além do preparo médico especializado, também cumpria ao médico possuir dotes de espírito que permitissem abranger filosoficamente $o$ conjunto das ciências relacionadas com a pedagogia (STEPHANOU, 2006b, p 41).

Essa inter-relação e valorização dos saberes médicos foram propagandeadas no ideário higienista já no final dos anos 1920, vindo com força nas décadas de 1930-1950. Essas mensagens, além de serem reforçadas nos currículos escolares, na presença de práticas médicas nas escolas, em manuais e livros didáticos, foram veiculadas também em almanaques, manuais médicos prescritivos ${ }^{13}$, e também em revistas dirigidas ao público infantil, como é o caso de O Pequeno Luterano. Nada mais útil para uma revista que tinha objetivos religiosos e educativos, veicular textos que exortassem e controlassem os seus fiéis, podendo estabelecer relações entre higienismo, moralidade e doutrina.

Nas leituras de O Pequeno Luterano, essas mensagens do higienismo aliam-se ao nacionalismo ufanista enfatizado na época. Com o culto à Pátria, são reforçados também preceitos do militarismo ${ }^{14}$ através da educação física nas escolas, já que esta disciplina atenderia uma demanda de valorização do corpo para a formação de bons cidadãos, disciplinados e ordeiros.

Muitos artigos da revista estão relacionados à higiene, saúde e patriotismo, sendo cada vez mais recorrentes na revista, especialmente entre as décadas de 1930-1955. O Sínodo de Missouri não estava alinhado ao movimento germanista promovido por outras instituições luteranas, mas era uma instituição que tinha entre a maioria de seus fiéis descendentes germânicos. Assim, infere-se que era preciso reforçar os valores patrióticos e os valores higienistas para evitar perseguições do Estado Novo.

Ainda em publicação na língua alemã, a preocupação com os hábitos higiênicos é destacada e relacionada aos princípios doutrinários cristãos.

Não esquecer a limpeza dos dentes

Volto mais uma vez sobre a atenção a esta necessidade. Vocês não devem de esquecer este dever. Muitos são perturbados com as queixas dos dentes e com as dores. Mas está em vocês mesmos que estas queixas possam ser evitadas ou diminuídas. Para isto é necessário apenas um trato com os dentes. Cada um, com um pouco de dinheiro pode comprar uma escova de dente. Há também que comprar pasta de dentes para uma 
minuciosa limpeza. Certamente é necessário que de tempos em tempos procurem o dentista.

Quando eu recomendo a vocês um trato com os dentes é para não sofrerem mais tarde. O Apóstolo Paulo adverte aos cristãos, que vossos corpos devem ser tratados ordeiramente. Com o tratamento do corpo pertence também a limpeza dos dentes. Em torno disso ainda digo:

Não esquecer a limpeza dos dentes! (Kinderblatt, out/1937, p. 38-39).

O conselho sobre a limpeza do corpo é relacionado com a ordem moral e religiosa que, na revista, conforme se verificou até aqui, era preciso ressaltar. Evidencia-se um controle minucioso das práticas higiênicas concomitante a práticas religiosas, configurando um verdadeiro processo disciplinar. Com apoio em Foucault (1989), é possível melhor compreender estas práticas:

A disciplina é uma anatomia da política do detalhe. [...] Nessa grande tradição da eminência do detalhe viriam a se localizar sem dificuldade as meticulosidades da educação cristã, da pedagogia escolar ou militar, de todas as formas, finalmente, de treinamento [...] (FOUCAULT, 1989, p.120).

Tais cuidados apontam para um controle meticuloso e minucioso do corpo, não apenas no aspecto da higiene corporal, mas em relação ao comportamento moral e disciplinado. A maneira de andar, a atitude de não roer unhas mostram que os pequenos gestos e hábitos mereciam toda a atenção. Até mesmo em relação aos modos de leitura as orientações estão presentes na revista. A preocupação se dá desde a higiene dos olhos e até às maneiras de ler. Uma das histórias contadas no $\mathrm{O}$ Pequeno Luterano ilustra bem esta proposição:

\section{Pedro - um menino de bons hábitos}

Pedro, ao clarear o dia, salta de cama bem disposto. Veste-se e vai lavar o seu rosto. Saúda os pais e em sua companhia toma café. Antes de ir à escola dá uma última olhada nas lições e verifica se nada falta. Despedese do papai e da mamãe e dirige-se logo após diretamente á escola. (...) Chega pontualmente. Na aula, Pedro é atencioso e comportado. (...) Os seus exercícios mostram capricho e asseio. No recreio é bom companheiro. (...) Finda a aula, sem demorar, volta ao lar paterno. Evita as más companhias. Na rua não grita, nem briga (...) (O Pequeno Luterano, jun, 1947, p. 23).

Assim como o Higienismo, o Alerta de Doenças conta com textos de exortação moral e higienista. $\mathrm{O}$ espaço educativo da revista era ocupado com estes textos, porque no espaço escolar seria necessário organizar a saúde pública da população. Os investimentos no setor da saúde neste período eram ínfimos, e seria naturalmente mais econômico a escola se ocupar com a educação para a saúde.

Cabe registrar que anúncios de remédios são recorrentes na revista a partir da década de 1960. De certa forma serviram para financiar os custos ${ }^{15}$ divulgando remédios comuns - para evitar doenças simples, como verminose, gripes, problemas estomacais - e fortificantes para memória e para o físico. De modo geral, tais textos são prescritivos e informativos. 
Outros excertos sobre o $\mathrm{ABC}$ de Saúde são apresentados na revista, retirados do Serviço Nacional de Educação Sanitária, um órgão do governo que direcionava os assuntos sobre higiene.

\section{B- Banho}

O BANHO é indispensável ao asseio e saúde individuais. Quando frio, ativa a circulação do sangue e, tomado diariamente, põe a pele em condições de resistir melhor às mudanças de temperatura.

Tome banho diáriamente. Prefira, porém, o banho frio pela manhã, ao levantar-se. (sic?)

S. N. Educação Sanitária (PEQUENO LUTERANO, Ano VII, $n^{\circ}$ 9, setembro de 1951, p 41, disposição e grifos da revista)

Este texto apresenta indicações de higiene ao lado das comemorações do 7 de setembro ligando o higienismo ao civismo presente neste contexto. As indicações fazem parte de um discurso que era oficial no período político que o país vivia como preservar e limpar a população com hábitos de higiene e de conduta moral. Contudo, os preceitos higienistas se sustentavam através dos princípios morais e religiosos.

\section{Considerações Finais}

Importante consideração a fazer na conclusão do artigo diz respeito à expansão do Sínodo, no final da década de 1930 e início da década de 1940. Como movimento estratégico o trabalho doutrinário foi sustentado em parte pela diversidade de publicações destinadas a diferentes faixas etárias, e em parte pela preocupação latente em adaptar as escolas étnicas às políticas de nacionalização do ensino. Como instituição religiosa, investiu em táticas por força de modelos impositivos do Estado Novo. Acabou sendo obrigada a modificar os materiais impressos, além da forma de escolarização de seus fiéis quanto à questão linguística, buscando estrategicamente não entrar em confronto direto com políticas governamentais vigentes no país. Na medida do possível, buscou agir de forma neutra e pacífica como forma de sobrevivência. Deste modo, a intensa publicação de seu material religioso continuou circulando nas comunidades e pôde se consolidar entre grupos religiosos de interesse.

A formação do cidadão, articulando valores morais e pátrios, visava estimular condutas que não incluíam questionamentos, pelo contrário, previa uma conduta passiva e subserviente diante da realidade social, reforçada em histórias bíblicas e doutrinárias, em determinado período incluindo valores nacionalistas. Assim, visando "projeto de futuro", a revista reforçava condutas aceitáveis, propondo constante auto-avaliação do comportamento do leitor como aluno, vinculado ao comportamento como cristão.

De forma geral os conhecimentos seculares serviram na formação do leitor/aluno/cristão/cidadão. Através do mapeamento dos dados, percebe-se nos conteúdos da revista, parte do currículo escolar a ser desenvolvido nas escolas, tanto nos aspectos de conhecimento, como de formação geral. Por isso, estes aspectos abarcam muitos questionamentos da formação educativa e religiosa determinada pela revista. Vislumbra-se o espaço escolar como aquele em que o impresso irá dialogar daí a necessidade do contato com os leitores.

Os conteúdos de disciplinas seculares que apareceram no impresso complementam a educação escolar. Na análise foram consideradas gerais, porém com certa conotação religiosa, ou seja, mesmo os conteúdos de conhecimento geral, quase sempre vinham acompanhados de elementos religiosos. O "higienismo" e "nacionalismo", presentes em determinada época, contribuindo com a formação moral do cidadão, fomentando condutas morais de aparente neutralidade. Assim, encontraram-se temas 
traduzindo nacionalismo e ufanismo, pautado na história factual e no civismo, a revista seguindo, rigorosamente, a publicação e exaltação de datas cívicas no decorrer do ano letivo.

Apesar de a instituição do Sínodo de Missouri, por diversas vezes, negar nas revistas e na orientação geral da igreja que estivesse atrelada a qualquer movimento político (reforçado nos momentos mais críticos e tensos da história brasileira, como no período de nacionalização do ensino), percebe-se que tomava posições ou de neutralidade, ou de defesa do governo do Estado Novo. Também de forma tímida, mas nítido na revista, há um reiterado discurso de passividade/neutralidade a partir do golpe civil-militar de 1964. Por isso, dados relativos ao tema "Política" não são recorrentes na revista, mas a ausência/silêncio deste aspecto é considerada relevante para fins de análise, na medida em que nas poucas vezes em que se menciona algum aspecto político, o mesmo emerge na tentativa de negá-lo ou de afastá-lo do universo religioso, e, por conseguinte, escolar.

No período de 1940, os valores da neutralidade/passividade política são fortes no discurso da revista. Foi necessário apaziguar os ânimos frente à perseguição do Estado Novo, tanto em relação às escolas, como às igrejas. O material impresso sofria mecanismos de censura e controle pelo estado. A primeira adaptação foi quanto à questão linguística, na mudança da língua alemã para a língua portuguesa, tendo, provavelmente grande impacto nas relações da edição/leitores. $\mathrm{O}$ formato da revista em si não teve alterações, mas com respeito à questão política, a edição precisou se manifestar de forma passiva e subserviente. De fato, uma forma de sobrevivência do impresso e de sua proposta básica inicial. Os textos eivados dos princípios nacionalistas revelam a presença de preceitos políticos e a editoração alinhando-se a preceitos conforme o contexto vigente. Precisava do aval do poder público para assegurar a disseminação doutrinária, o aprendizado da Bíblia e dos valores morais entre as crianças leitoras. Enfim, é possível supor que muitos leitores acompanharam o contexto da revista, provavelmente sendo orientados pelos conhecimentos seculares, conforme as diferentes estratégias sugeridas no editorial. Como a produção e circulação do referido impresso apresentam especificidades próprias, e a apreensão dos textos sugerida aos leitores não são previsíveis, muitas táticas por parte dos leitores, sem dúvida, puderam escapar ao controle rigoroso e minucioso do empreendimento. Tal constatação permite dizer que, ao apresentar críticas e/ou silêncios frente a determinadas ideias, os leitores talvez estivessem também, ao mesmo tempo, fazendo reflexão sobre elas.

\section{Referências:}

ARENDT, Isabel Cristina. Representações de Germanidade, Escola e Professor no AllgemeineLeherzeitungfuer Rio Grande do Sul (Jornal Geral para o Professor do Rio Grande do Sul). São Leopoldo, Unisinos, Programa de Pós-Graduação em História, Tese de Doutorado, 2005.

BICCAS, Maurilane de Souza. O Impresso como Estratégia de Formação: revista de Minas Gerais (1925-1940). Belo Horizonte, Argumenton, 2008.

CAPELATO, Maria Helena Rolim. Multidões em cena. Propaganda no varguismo e no peronismo. Campinas, Papirus, 1998.

CERTEAU, Michel de. A Invenção do Cotidiano. 17 ed. Petrópolis, RJ, Vozes, 2011.

CERTEAU, Michel de. La escritura de la historia. 3. ed. México: Universidad Iberoamericana, 1993. 
CHARTIER, Roger. Formas e Sentido Cultura Escrita: entre distinção e apropriação. Campinas, Mercado de Letras; Associação de Leitura do Brasil, 2003.

CHARTIER, Roger. À Beira da Falésia: a história entre incertezas e inquietude. Porto Alegre, Ed Universidade, UFRGS, 2002.

CHARTIER, Roger. La Revolucione de la cultura escrita. Barcelona, Gedisa, 2000.

CHARTIER, Roger. A Aventura do Livro do leitor ao navegador conversações com Jean Lebrun. São Paulo, UNESP, 1999.

CHARTIER, Roger. A Ordem dos Livros: Leitores, autores e bibliotecas na Europa entre os séculos XIV e XVIII. Editora Universidade de Brasília, 1994.

CHARTIER, Roger. El Mundo como Representación: estúdios sobre historia cultural. Barcelona, Gedisa, 1996a.

CHARTIER, Roger. Do livro a leitura. IN: CHARTIER, Roger. Práticas de Leitura. São Paulo, Estação Liberdade, p 77-106, 1996 b.

CHARTIER, Roger. A leitura: uma prática cultural Debate entre Pierre Bourdieu e Roger Chartier. . IN: CHARTIER, Roger. Práticas de Leitura. São Paulo, Estação Liberdade, p 231-254, 1996b.

CHARTIER, Roger. Textos, impressão, leituras. IN: Hunt, Lynn. A Nova História Cultural. São Paulo, 1992.

CHARTIER, Roger. A História Cultural entre práticas e representações. Lisboa, Difel, s/d.

D’AMBRÓSIO, Ubiratan. A etnomatemática no processo de construção de uma escola indígena. Em Aberto, Brasília, ano 14, n.63, jul./set. 1994.

FOUCAULT, Michel. Vigiar e Punir. Petrópolis, Vozes, 1989.

GERTZ, René. O Perigo Alemão. $2^{\text {a }}$ ed. Porto Alegre, Universidade/ UFRGS; 1998.

GOMES, Angela de Castro (Org.). Capanema: o ministro e seu ministério. Rio de Janeiro: 2000.

KREUTZ, Lúcio. Professor Paroquial: magistério e imigração alemã. Pelotas, Seiva, 2004a.

KREUTZ, Lúcio. Currículo Escolar, Culturas e Imposição de Língua Única. Anais do X Encontro Sul-Riograndense em História da Educação. Pelotas, Seiva, 2004b, p. 215-227.

KREUTZ, Lúcio. Língua de Referência na escola teuto-brasileira. IN: CUNHA, Jorge Luiz da e GARTNER, Angelika (orgs). Imigração Alemã no Rio Grande do Sul: história, linguagem, educação. Santa Maria, UFSM, 2003, p. 133-157

RAMBO, Arthur Blásio. O teuto-brasileiro e sua identidade. IN: FIORI, Neide Almeida (org.). Etnia e educação: a escola alemã do Brasil e estudos congêneres. Florianópolis, Tubarão, UFSC, Unisul, 2003, p. 71-89.

RAMBO, Arthur Blásio. A igreja dos Imigrantes. IN: DREHER, Martin (org.). 500 anos de Brasil e Igreja na América Meridional. São Leopoldo, EST, 2002, p. 57-73

RAMBO, Arthur Blásio. Nacionalidade e Cidadania. IN: MAUCH, Claúdia e VASCONCELLOS, Naira. (org.). Os Alemães no sul do Brasil: cultura, etnicidade e cultura. Canoas, ULBRA, 1994, p. 43-53. 
SCHWARTZMAN, Simon / BOMENY, Helena Maria Bousquet / COSTA, Vanda Maria Ribeiro. Tempos de Capanema. São Paulo: 1984.

SEYFERTH, Giralda. A identidade teuto-brasileira numa perspectiva histórica. IN: MAUCH, Claúdia e VASCONCELLOS, Naira. (org.). Os Alemães no sul do Brasil: cultura, etnicidade e cultura. Canoas, ULBRA, 1994, p. 11-27.

SAVIANI, Demerval. História das ideias pedagógicas no Brasil. Ed. Autores associados, Campinas, 2008.

SOARES, Carmen Lúcia. Educação física: raízes européias e Brasil. Campinas: Autores Associados, 1994.

SOARES, Carmen Lúcia. Imagens da educação no corpo; estudo a partir da ginástica francesa no século XIX. Campinas: Autores Associados, 2002.

SOUZA, José Carlos Araujo \& GATTI, Décio Junior (org). Novos temas em História da Educação Brasileira: instituições escolares e educação na Imprensa. Campinas, Autores Associados, 2002.

STEPHANOU, Maria. Prefácio. Nem uma coisa, nem outra ou nenhumas. (Re) invenções e reminiscências escolares. A modo de prefácio. In: FISCHER, Beatriz T. Daudt.(org) Tempos de escola: memórias. São Leopoldo, Oikos, 2011.

STEPHANOU, Maria. Bem viver em regras: urbanidade e civilidade em manuais de saúde. Educação Unisinos. jan/abril, p 35-44, 2006a.

STEPHANOU, Maria. Discursos médicos, educação e ciência: escola e escolares sob exame. Trabalho, Educação e Saúde. v 4, n 1, p 33-64, $2006 \mathrm{~b}$.

WANDERER, Fernanda. Escola e Matemática Escolar: mecanismos de regulação sobre sujeitos escolares de uma localidade rural de colonização alemã no Rio Grande do Sul. São Leopoldo, Unisinos, 2007. Tese de Doutorado.

WARTH, Carlos H. Crônicas da Igreja: Fatos históricos da Igreja Evangélica Luterana do Brasil: (1990-1974). Porto Alegre, Concórdia S. A ., 1979.

WEIDUSCHADT, Patrícia. A revista "O Pequeno Luterano" e a formação educativa religiosa luterana no contexto pomerano em Pelotas- RS (1931-1966). Programa de PósGraduação em Educação. Unisinos. São Leopoldo, 2012. Tese de doutorado.

WEIDUSCHADT, Patrícia. O Sínodo de Missouri e a educação pomerana em Pelotas e São Lourenço do Sul nas primeiras décadas do século XX l-identidade e cultura escolar. Programa de Pós-Graduação em Educação. FAE/UFPEL, Pelotas, 2007. Dissertação de Mestrado.

\section{Periódicos e revistas pesquisadas:}

Evangelisch-Lutherisches Kinderblat Sued-Amerika, Casa Publicadora Concórdia, Porto Alegre, 1931-1939. Revista Oficial da Igreja Evangélica Luterana do Brasil.

O Pequeno Luterano, Casa Publicadora Concórdia, Porto Alegre, 1939-1966. Revista Oficial da Igreja Evangélica Luterana do Brasil. 


\section{Notas:}

${ }^{1}$ Professora efetiva da Universidade Federal de Pelotas. Doutora em Educação pela UNISINOS. Email: prweidus@gmail.com

${ }^{2}$ Professora da Universidade do Vale do Rio dos Sinos. Doutora em Educação. Email: bea.df@terra.com.br

${ }^{3}$ A revista "O Pequeno Luterano"serviu como objeto principal da tese de doutorado, defendida em janeiro de 2012. WEIDUSCHADT, Patrícia. A revista "O Pequeno Luterano" e a formação educativa religiosa luterana no contexto pomerano em Pelotas- RS (1931-1966), sendo analisada em um banco de dados minucioso e sob diferentes aspectos. O trabalho considerou a importância da revista em relação à educação cristã e escolar dos fiéis. A revista orientou os fiéis na doutrinação luterana, mas também fortaleceu a educação secular, sendo este aspecto tema central deste artigo.

${ }^{4}$ O campo da História da Educação tem se ampliado e fortalecido através de pesquisas que tomam como objeto e fonte diferentes tipos de impressos como: jornais, revistas especializadas ou não na área da educação, mas que contribuem significativamente para o entendimento de processos educacionais. Ver em SOUZA, José Carlos Araujo \& GATTI, Décio Junior (org). Novos temas em História da Educação Brasileira: instituições escolares e educação na Imprensa. Campinas, Autores Associados, 2002. BICCAS, Maurilane de Souza. O Impresso como Estratégia de Formação: revista de Minas Gerais (1925-1940). Belo Horizonte, Argumenton, 2008

${ }^{5}$ Dissertação defendida em maio de 2007, na Universidade Federal de Educação no Programa de PósGraduação em Educação com o título O Sínodo de Missouri e a educação pomerana em Pelotas e São Lourenço do Sul nas primeiras décadas do século XX : identidade e cultura escolar.

${ }^{6}$ Segundo dados das Crônicas da Igreja, organizada por Warth (1979) em 1924 eram 68 escolas, 2028 alunos atendidas por 25 pastores, 37 professores e 4 estudantes. Apesar das dificuldades nos anos 1920 e 1930, com ameaça de fechamento por funcionarem na língua alemã, de 3668 em 1938 a matricula subiu para 7784 alunos em 1957, tendo 5557 em 1966, em 1973 eram 8524 alunos, entrando em declínio na década de 1980.

${ }^{7}$ Para aprofundar e referendar sobre os embates das comunidades de imigração alemã em relação a nacionalização do ensino ver em ARENDT , 2005, KREUTZ(2004a, 2044b, 2003), RAMBO (2003, 2002, 1994), GERTZ (1998).

${ }^{8}$ A título de ilustração, menciona-se a construção de práticas matemáticas a luz da etnomatemática (D' AMBRÓSIO, 1994, KNIJNICK, 2003), em que cada grupo constrói práticas e saberes específicos de acordo com o contexto. Assim a matemática, aparentemente, poderia ser um conhecimento universal, mas o conhecimento matemático se constitui a partir dos interesses do grupo. No caso da pesquisa, a valorização da matemática por imigrantes alemães estaria dentro da constituição de saberes práticos e racionais, mas inseridos no cotidiano, e no caso da instituição do Missouri, integrava os conhecimentos matemáticos com os conhecimentos bíblicos. Para saber mais ver em : WANDERER, Fernanda. Escola e Matemática Escolar: mecanismos de regulação sobre sujeitos escolares de uma localidade rural de colonização alemã no Rio Grande do Sul. São Leopoldo, Unisinos, 2007. Tese de Doutorado.

${ }^{9}$ Nas edições de 1944 até nov/dez de 1946, todos os meses ao final da edição apareciam os dizeres: “Autorizado a circular pelo D. I. P.- Proc. 9654/40". O departamento em questão era o Departamento de Informação e Propaganda, o qual estava fiscalizando as circulações impressas no país.

${ }^{10}$ Prova desta resistência se concretizar é a manutenção de alguns impressos em alemão, em especial, aos destinados ao público adulto, que tinham se alfabetizado na língua alemã e não aprenderam a leitura da língua portuguesa. Os impressos Kirchenblatt e Lutherkalender foram mantidos, mesmo depois da nacionalização.

${ }^{11}$ A título de ilustração, a história denominada "As portas do seminário estão abertas", indica a postura que as crianças e jovens devem ter em relação aos mais velhos. De forma resumida, a história relata a passagem bíblica de Eli, orientador de Samuel, o qual via os seus pais uma vez por ano. Ele era diferente dos filhos de Eli que eram maus e não eram repreendidos, mas um dia Samuel recebeu um aviso que os filhos de Eli seriam castigados. Quem não obedece a Deus é castigado. Assim, muitos podem ser pastores e professores 
para seguir a Cristo e orientar as demais pessoas que não são obedientes (O Pequeno Luterano, out/1963). Neste caso, a obediência é treinada e moldada para Cristo, mas, acima de tudo, ela é voltada para Deus.

${ }^{12}$ Em número menor, mas não menos significativas, são as histórias ligadas a Datas Cívicas e conhecimento histórico, em que são reforçados valores de nacionalismo, colocando a cultura indígena como aquela que precisou ser civilizada pelos brancos, especialmente, em se tratando da religião. Percebe-se na análise que o eurocentrismo mantinha relações com o ideário político, embora o Sínodo fizesse questão de reforçar a sua neutralidade, acabava condenando governos comunistas e que não tivessem alinhados a projetos cristãos $(\mathrm{O}$ Pequeno Luterano, A missão entre os selvagens, jan-fev/1958: A Índia, jul-ago/1959; O grande Deus Triúno, jul-ago/ 1962).

${ }^{13}$ Maria Stephanou aborda o uso de mensagens higienistas direcionadas para o público em geral através de manuais de saúde. Estes se transformaram em livros com autores médicos e eram veiculados através da imprensa: "Os manuais sobre os quais me detive foram objeto de significativa circulação e difusão, sendo manifesta a preocupação do Dr. Mário Totta, seu autor, em atingir diferentes grupos sociais. Embora descuidados pelas investigações no âmbito da História da Educação constituíram-se em meios educativos por excelência, voltados especialmente à população das cidades e visando a uma educação sanitária para além das escolas. Mais do que um conteúdo instrucional, os manuais se colocam como dispositivo privilegiado no que se refere à produção de novas subjetividades, identificadas com as atenções a dispensar a si mesmo, produzir-se como sujeito de uma higiene, uma educação e uma conduta próprias à urbanidade e, afinal, "civilizadas"'(STEPHANOU, 2006a , p. 42).

${ }^{14}$ Não se pretende aprofundar a formação da ênfase militarista na educação física no Brasil, mas entende-se que cabe destacar este movimento, o qual auxiliou na formação de um ideário nacionalista, ufanista e, também, dos ideais higiênicos. Para saber mais sobre o militarismo e educação física, ver SOARES ( 2002; 1991).

${ }^{15}$ De acordo com a entrevista dos editores, Alípio e Wanda Linden, a revista aumentou muito o número de páginas, antes do fechamento, devido ao apoio da propaganda e da publicidade.

Recebido em abril/2012

Aprovado em agosto/2012 